\title{
PRECARIOUS WORK, CITIZENSHIP AND THE LAW: CHALLENGES AND OPPORTUNITIES
}

\author{
Amanda Reilly \\ School of Accounting and Commercial Law \\ Victoria University of Wellington
}

\begin{abstract}
Work, even precarious work, is often assumed to be the path to social inclusion for citizens. Hence, over recent years, Western Democracies have through law changes allowed, and sometimes encouraged, precarious work to increase. However, it is suggested that in a democracy, rather than solely concerning itself with the inclusion of citizens in the workforce, the state ought to facilitate political participation and equality between citizens. Precarious work, as currently organised, is examined and found antithetical to these goals.
\end{abstract}

The paper draws on European and feminist labour law theory to envision a future where precarious work is liberating and conducive to citizens' full participation and inclusion in all aspects of life. Some areas for possible legal reforms that could help the realisation of this vision in New Zealand are outlined.

\section{Introduction}

This paper is concerned with precarious workers. Precarious work is poor quality, insecure work. It tends to be low-skilled and offers little in terms of training or potential for advancement. Precarious workers are at higher risk of poverty and of work-related injury and illness. They are frequently to be found in non-standard work arrangements such as on fixed term contracts or as self-employed, subcontracted temporary employees. (Tucker 2002)

Internationally there has been an increase in precarious work. There are many reasons for this. In Western liberal democracies law changes consciously aimed at improving flexibility by weakening the protection of labour and employment law have undoubtedly played a role.(Dannin 1997; Toynbee 2004)

This paper focuses on the underlying reasoning which suggested it would be for the good of the individuals concerned as citizens if the law were to be reformed so as to encourage an increase in precarious work, if, consequently, more jobs were generated and more individuals involved in the workforce. (Toynbee 2004) This reasoning saw those in precarious work effectively lose the protection of labour and employment law that as employees they might formerly have had.

\section{Thesis and Structure of Paper}

The central thesis of this paper is that it is not justifiable to remove a group of people from the protection of the law in order to improve their functioning as citizens by effectively coercing them to accept inferior work. When closely examined, precarious work is seen to be antithetical to citizenship.
However, since social institutions do not remain static, and it seems likely that forms of work are changing, the law surrounding work must change too. When the normative meaning and purpose of citizenship is examined criteria emerge to guide the formulators of new laws who wish to take account of individuals as citizens and not merely as workers. Some thoughts on the future direction of law, which take account of these criteria, are then discussed

\section{Methodology}

Legal reform is always underlain by normative choices. In this paper a set of norms is explicitly articulated so as to form the basis of suggestions for future law change

\section{The Meaning and Purpose of Citizenship}

It has been suggested that it was viewed as justifiable to enact law reform that effectively encouraged precarious work. This is because it was seen as having benefits for the people involved since they would become participants in the workforce. The justification for the law reforms can thus be seen as being concerned with the individuals' participation and functioning in the group membership that is society i.e. citizenship. Work has assumed a central position in the ideology of the state and "the citizen is valued first and foremost as economic man.”(Kelly 2000)

The perceived citizenship benefits to individuals of participation in the workforce can be encapsulated by two key concepts.

1) Inclusion

2) Independence

It is now argued that these two concepts do not present a full picture of the meaning and requirements of 
citizenship. A fuller, richer, alternative description of citizenship is offered, which shows that precarious work, as currently constituted is not a suitable vehicle for encouraging citizenship.

\section{Inclusion}

The idea of inclusion through participation in the workforce is a central plank of social democratic third way regimes. (Giddens 1998) This emphasis underlay much of the reform, which resulted in the growth in precarious work. (Toynbee 2004)

Nobody could be opposed to inclusion as a vague general concept. Nor could anybody be in favour of alienation and exclusion. But there are more ways of being included in society than merely through the paid work. (Bauman 1998: Gorz 1999) Inclusion as a citizen means more than just inclusion by economic participation in the workforce. Citizenship is generally understood to be concerned with political participation. Thus, a citizen is included where they have the means and the opportunity to participate in political discourse and activity. (Birch 1993)

\section{Independence}

The ideal of independence is central to liberalism. Liberalism presents the self-supporting, autonomous rational individual as being the norm. Dependence is an aberration. So, with this view in mind, it makes sense to strongly encourage citizens into work that allows them to be self-supporting, no matter how poor the quality of that work.

However, the liberal concept of independence has been powerfully critiqued by feminist analysis. (Fredman 1998; Kessler 2001) Dependence is not an aberration. We all spend much of our lives dependent on others at various times. Society is not just a conglomerate of individuals. We are connected by mutual need and dependence in which the family plays a central role. (Fineman 1998) These connections, with their associated unpaid nurturing, underlic all else, as without them there would not be any participation in the workforce or political life, or indeed any new citizens. (Fredman 1998)

So the ideas of inclusion and independence through participation in the workforce are shown to be an incomplete and limited conception of the meaning of citizenship. Workforee participation can only be one part of what it means to be a citizen. The citizen must also be recognised as a political being and as a being with a private life. with associated care-giving responsibilities and needs.

The following are now offered as alternative requirements for the facilitation of eitizenship:

1. Equality is required for true enfranchisement of citizens. Equality is what enables all citizens to participate in the enforement of existing rights as well as in the framing of new rights. Without equality existing rights will be undermined and democracy and citizenship will come under threat. (Pateman 1970; Janoski 1998)
2. A rich civic life and time and space for political discourse are needed to allow citizens to formulate views and to participate in the political life of society. (Kohler 1995)

3. And underpinning it all there must be recognition of the fundamental importance and value to society of families and unpaid care-giving. (Fredman 1998)

It is now suggested that, when judged by these criteria, precarious work is not a good basis for citizenship.

\section{The Challenge of Precarious Work}

\section{Equality}

Precarious workers are kept to the fringes of the workforce (Klein 2000), denied opportunities for advancement and training, are subject to greater health risk, and are economically insecure. Women and minorities are the majority of precarious workers. (Fredman 2004)

Precarious work is thus concentrated among marginalised and politically disadvantaged groups as both a source and a symptom of disadvantage and inequality.

\section{Rich Civic Life and Time and Space for Political Discourse}

It has been suggested that inclusion in the workplace is not all there is to citizenship. This is not to deny that work is an important part of the life of citizens. Amongst other needs it fulfils, there is evidence to show that work is one of the main ways people interact politically, in the sense of discussing political events with others.(Kohler 1995; Estlund 2003)

Work can also be an important means whereby, through long term association, workers get to know different sorts of people and through daily contact and conversation develop understanding, empathy and a sense of commonalities across class, gender, age group and racial lines. This contributes to greater equality and integration across society (Estlund 2003) as well as to the building of trust. (Sennet 1998)

Precarious workers are not entirely excluded from work, as an important form of civic and political association, in the way the long-term unemployed might be. They are however perpetually on the fringes of working life and hence of this form of civic association.(McAllister 1998)

Workplaces are one possible space for civic life but there are a vast range of other spaces such as grass roots political movements, clubs and so forth. However the insecurity of the lifestyle associated with precarious work i.c. of alternately being over-worked then under-worked, with irregular hours and unreliable income is not conducive to regular stable participation in non-work activities either. (McAllister 1998) 


\section{Recognition and Support of Families}

The lifestyle described above is destructive to families as well as to general participation in non work activities.(Mc Allister 1998)

\section{Conclusion}

Citizenship in a participatory democratic society requires equality between citizens and a diverse and relatively stable civic life which recognises the underlying importance of the family responsibilities that keep society going.

This is as opposed to the fragmented, atomistic, alienated and isolated (Schultz 2000) and ultimately non-conducive to citizenship lifestyle that precarious work tends to foster

\section{The Opportunity of Precarious Work}

Many people voluntarily choose non-standard working arrangements in order to spend time with their families, and to take part in non-workplace oriented activities. Precarious workers are disadvantaged because they do not have freedom of choice and the precariousness of their working arrangements serves to keep them unequal and alienated.

Non-standard working arrangements could potentially present an empowering life and citizenship enhancing option if made available as a choice to everyone. However this will require redesigning the laws surrounding work.

Such a redesign should take account of the following three criteria. First, precarious work or rather atypical working arrangements must not be a source of marginalisation and disadvantage. Secondly, there must be spaces and time for civic discourse. Thirdly, there must be recognition and support of the unpaid work, traditionally viewed as women's work, which underlies all human activity.

Three areas for future law reform are now outlined:

1. unions.

2. the regulation of time.

3. equality at work.

\section{Unions}

There are three ways that unions have historically been expected to improve the terms and conditions of workers and hence their opportunities to participate as citizens. (Stone 2001)

These are:

(a) Collective bargaining for improved conditions of employment.

(b) Providing services such as legal advice and representation for individuals pursuing grievances

(c) Political mobilisation.
The benefits to precarious workers of union membership are now described.

\section{Collective Bargaining}

If unions succeed in collectively bargaining for improved terms and conditions for precarious workers, these workers will be able to function better as citizens. They will have more means with which to participate in life in general. They will be less disadvantaged generally (e.g. in terms of occupational safety and health) and thus will have more time and energy to put into engaging in social dialogue and non-work forms of association.

Unions have always had a tendency to shape themselves around the way that production is managed. (Supiot 2001) And the laws which unions are constituted within have facilitated this process. The present day union movement and the laws surrounding it had their roots in a Taylorist system of production.

Unions within a Taylorist model are primarily concerned with collective bargaining focused on achieving better terms and conditions for a securely employed long term, full-time male workforce. Within this model jobs can be broken down into easily identifiable, standardised tasks. And within the organisation there is a clear hierarchical internal career ladder, which the employee may expect to ascend in due course by virtue of seniority. In such a framework the union's main focus is to bargain for incremental improvements in employment conditions based on seniority.

The Taylorist model of collective bargaining as sketched above is in some respects unsuited to dealing with the issues facing the precarious workforce and new ways of structuring work. For example, any bargaining related to pay rises and benefits based on longevity is irrelevant to precarious workers, particularly if bargaining is enterprise-specific. Precarious workers never gain a toehold on the internal career ladders and have tenuous, transitory attachments to particular workplaces.

However, while the traditional Taylorist model concentrates on employees there is no reason, in principle why collective bargaining cannot be extended to other groups of workers. In Europe there are initiatives to unionise previously un-unionised workers such as temps and dependent contractors to enable them to bargain for better terms and conditions. These have met with some success and arguably should be facilitated here in New Zealand.

\section{Legal Representation}

If the goal is to protect and further the interests of precarious workers, then passing laws to do this and negotiating collective contracts is only half the battle. The other half of the battle is to ensure that laws and contracts are enforced. Unions can play an essential role in making sure that this happens through providing legal representation for individuals and fighting for the rights of workers in the courts. These include rights such as the right to non-gender discrimination as well as any rights 
more specifically aimed at the interests of precarious workers. Legal action not only has the potential to benefit individual workers, it also may establish useful precedents. In addition it keeps the plight of the worker before the public eye. (Stone 2001)

\section{Political Mobilisation and Deepening the Roots of Democracy}

It is suggested that precarious workers should be in unions for more fundamental citizenship reasons than just the benefits of improved conditions at work. Unions are part of working life but they also have a separate identity as part of civic life. They foster not only workplace democracy but also, by doing so they "deepen the roots of political democracy."

Collective bargaining, at its best, can be seen as a conversational activity. (Kohler 1995) The union creates and sustains relationships and webs of conversation between people and facilitates consensus as to how a workplace should be organised. Kohler suggests that collective bargaining is akin to a system of private lawmaking. By participating in collective bargaining about, for example, promotions and policies regarding gender equity, workers are involved in formulating the law and policy that most directly determines the detail of their lives. This strengthens democracy within the workplace as well as democracy in a broader societal context as it helps to develop good habits for citizenship by improving workers' sense of their political efficacy. (Pateman 1970)

There are thus strong citizenship arguments in favour of extending union membership and representation to the precariously employed.

There has been a general international drift away from collective association. This was strengthened by a concerted anti-union media campaign and by laws systematically designed to weaken union power.(Dannin 1997) However, if the objective is to strengthen union power it ought to be possible to reverse the process.

This is already happening within New Zealand to a certain extent. The passage of the Employment Relations Act goes some way towards this by affirming the importance of collective bargaining.

In this section it has been argued that the union movement has much to contribute to addressing the problems associated with precarious work. It can improve the working conditions of precarious workers through the power of collective bargaining and it can play a part in seeing that collective contracts and laws aimed at protecting workers are adhered to. It was also argued that there are benefits for democratic discourse in general in the existence of an active and vibrant union movement that includes precarious workers.

But, there are other non-work related organisations that can also provide forums for conversation and that can speak for workers' non-work related interests in political forums c.g. environmental and consumer action groups.
These groups can, if mobilized, exert some pressure for improved working conditions.(Klein 2000)

However, for this to happen there needs to be time and space for citizens to engage in non- work related forms of political association. In this respect it is very encouraging to note recent union initiatives in New Zealand campaigning for the lessening of working time.(New Zealand Council of Trade Unions)

\section{Citizenship, Work and Concepts of Time}

Changed patterns of work call for a re-thinking of time and its regulation. If precarious work is no longer to be a source of disadvantage and inequality there must be allowance made for time for citizenship activities and family activities. This section of the paper considers the implications of this rethinking of time in relation to individuals and to the community as a whole.

\section{Changing How We View Time}

Attitudes towards time and modes of regulating it are not static. Prior to the industrial revolution the concept of working time was less significant than it now is (Supiot 2001) Following industrialization where the Fordist production model came to be viewed as the dominant paradigm of work certain features emerged in the conception of time. Time was viewed as an objective reference and tool in the regulation of working relations resulting in the legal limitation of working hours. While this was beneficial in some respects, especially to workers who actually worked in Fordist type work environments, it also had detrimental effects; it led to a false dichotomy between "working time" and "free time" and treated unpaid work as irrelevant.

Household work and childcare occur in so-called free time. And as they do not occur during employed workers' working time they are not counted as work. But in a very real way it is essential that these activities occur, not only for the worker to take his/her place in the workplace but for the long-term survival of society.

Academic and vocational training are also necessary for much workplace participation but they frequently take place on the worker's "own time". In fact much "free time" is taken up with activities necessary to facilitate work, such as commuting.

Arguably in a precarious, changed work environment, work is increasingly encroaching upon "free time." with negative implications for individuals as citizens. Workers generally have less bargaining power to refuse pagers, mobile phones and the requirement that they be constantly available by email or on-call.

The dichotomy between working time and free time, if it was ever valid, is less so now. Notably all the above "free time" activities are not paid for by employers but by the workers or by society. This is even more so in a precarious environment where workers are disposable and employers have no long-term stake in their employees' well being. 
Supiot suggests that laws that continue to treat working time as an objective reference should be rethought. He suggests that "time must be envisaged not only as working time, as a measure of the exchange of work for pay but also as a subjective experience" It must take account of the entire story of human life both with regard to individuals and with regard to the community as a whole.(Supiot 2001)

The effect on individuals and the effect on community time of viewing time subjectively is now considered.

\section{The Effect On Individuals}

Taking account of the whole story of human life in formulating a concept of time involves accepting that in an increasingly precarious workforce individuals will go through a number of transitions in their life. The Fordist model based on a male earner who went through a relatively short period of training before commencing a career as an employee lasting for decades until retirement, rapidly followed by death can no longer be viewed as the norm. Instead it is likely that individuals will move between various forms of work throughout their lifetime including unpaid work such as periods of training and periods dominated by family responsibilities

The challenge is to ensure that this proves empowering to individuals as citizens rather than limiting. Measures to ensure transferability of seniority and benefits of paid work are one way to try to minimise the disadvantage to precarious workers as well as to improve their freedom in moving between paid jobs. Time taken out from wage earning should be seen as a normal stage in a career, not as a suspension in career.

\section{The Effect On Community Time}

It has been suggested that the regulation of working time should no longer be seen solely from the perspective of companies or the organization of paid work. However the necessary perspective must encompass more than just the preferences, needs and desires of individual workers. While the argument above would suggest that employers should be responsive to the needs and desires of individual workers, thus moving towards a subjective approach to the regulation of time, there are some dangers to citizenship in doing this. These too must be taken account of.

While it is true that individuals with more control over their own time may theoretically have greater opportunities to pursue worthwhile non-employment related citizenship activities this may be at a cost to communal time. Traditionally-regulated working time gives a sort of collective tempo to life. For example, traditionally after work socialising could be expected to occur in the evening as the majority were understood to be employed between 9 to 5 . While obviously this has never been the case for everyone, under a more individualised and subjective system of apportioning working time there is a danger that time devoted to all forms of social and civic life, already under pressure, will be squeezed even further as everyone struggles with different schedules. This has implications of all sorts of activities:- family life, provision of child care, shopping hours, the opening times of public facilities e.g libraries, as well as political and trade union type meetings

Supiot suggests that because there are larger societal interests at stake in the regulation of working time it should not be left entirely to the employer to determine. While much should be left to the parties to an employment agreement to determine in a decentralized manner, this must be supported by general legal principles of compatibility among the different sort of times. These principles should not be subject to derogation, but, at the same time the law should establish an appropriate forum for negotiation of details on a caseby-case basis. Supiot believes that collective bargaining is the necessary vehicle for achieving negotiation. (Supiot 2001)

\section{The Right To Equality At Work}

If we are to end the disadvantage and marginalisation of precarious workers, then workplace rights should be equally available to all workers.

Rights at work can flow from statute or common law or from collective or individual contract. (Edwards 1993) The rights associated with work can be divided into negative and positive rights.

Negative rights are those that protect the worker from abuse e.g. unfair dismissal provisions. Precarious workers are frequently unable to access these rights as they do not fall within the definition of employee.

Positive rights include the right to have an effective say in the decisions of the organisation that employs you. These rights have declined over recent years with a lessening of union power and the increase in precarious work. (Edwards 1993)

In the following discussion of workplace rights and precarious workers three main aspects are focused on:

1. Extending rights at work to all workers.

2. Developing new rights.

3. Equality through empowerment.

\section{Extending Rights at Work to All Workers}

The growth of precarious work is at least partly attributable to the fact that it enables employers to cut costs by giving precarious workers fewer entitlements than non-precarious workers. Hence rights associated with work are the most overt example of precarious workers 'inequality and marginalisation within society.

In classic labour law the rights attached to work flow from the existence of a contract of employment or an employment relationship. This is because, for a long time, the majority of workers fitted into the category of employee. Whether or not a contract of employment is held to exist depends on a range of common law tests, most centring around the notion of subordination. 
However, with changes in working patterns there has been a blurring of lines between employment and selfemployment and the introduction of multiple parties to the relationship such as with subcontracting or triangular relationships such as temping. As a result, in the last ten years there has been much litigation surrounding the issue of whether individual workers are employees or not; if they are employees they can access the rights associated with work and if they are not employees in the legal sense then they cannot.

Paradoxically, the rights and remedies provided by labour law, which are intended to be for the benefit of the disadvantaged, are becoming a prerequisite of the elite. That is, those who are in a secure, traditional employment relationship. Hence labour law legitimises inequalities between different categories of workers. If equality is to be furthered then there should be comparable protection for all workers.

The ILO concept of decent work has developed to try to deal with the inequalities presently arising from the limitations of classical labour law. (Hepple 2001) It explicitly refers to the importance of equality and calls for the extension of the scope of labour law beyond the traditional employment relationship. Incorporated into this is a search for solutions to ambiguities arising from triangular or multilateral employment relationships

The ILO concept also calls for basic protection for a broader group of working citizens. The ILO defines this group as workers doing all kinds of paid work in some relationship of dependency regardless of employment status.

\section{Developing New Rights}

In addition to extending existing rights to more workers new rights could be developed to accommodate the facts of greater insecurity for the work place as a whole.(Bolle 2002) A right to training and opportunities to learn new skills is one that suggests itself as important to precarious workers, both in terms of ensuring future employability and for maintaining a habit of learning that is important to citizenship. (Murphy 1993; Stone 2001)

\section{Equality through Empowerment}

While extending rights associated with work to a broader group of workers than are currently captured by existing legal definitions would go some way towards improving the situation and status of precarious workers in general, there is also a need for the implementation of positive duties to promote equality.

Hepple draws on insights from current regulatory theory to reaching the following conclusion: in designing a system of regulation intended to promote equality it is no longer sufficient to treat the issue of the enforcement of equality as a dialogue between the state and those being regulated (ie. employers). The disadvantaged groups themselves must be included as the quality of the regulation will depend on their empowerment. (Hepple $2001)$.
The catch-22 for precarious workers is that, as has been argued, the alienating effects of precarious work do not tend foster an environment or habits of citizenship that are likely to make them effective group participants in the regulatory process, even in the cause of furthering their own equality and interests. It remains critical that legal and political processes as far as possible are designed to be accountable and responsive to their needs

\section{Areas For Future Research}

If it is accepted that the law surrounding precarious work needs to be rethought with a view to promoting citizenship rather than towards merely encouraging participation in the workforce, then a number of areas for future research suggest themselves.

The proposals put forward in this paper relating to the role of collective bargaining, the regulation of time, and the principle of equality at work were of necessity within the constraints of a short paper, only sketched out. Much work remains to be done on filling in the detail of specific laws that could make the vision set forth here a reality.

\section{References}

Bauman, Z (1998) Work, Consumerism and the New Poor. Open University Press: Buckingham.

Birch, A (1993) The Concepts and Theories of Modern Democracy. Routledge: Open University Press.

Bolle, P. (2002) Perspectives: the dynamics of change and the protection of worker International Labour Review, 141, 275-290.

Dannin, E.J. (1997) Working Free. Auckland: Auckland University Press.

Edwards, R. (1993) Rights at Work: Employment Relations in the Post Union Era. New York: the Twentieth Century Fund Incorporated.

Estlund, C. (2003) Working Together: How Workplace Bonds Strengthen A Diverse Democracy. Oxford: Oxford University Press.

Fineman, M. (1998) The Inevitability Of Dependency And The Politics Of Subsidy. Stanford Law and Policy Review, 9, 9-23.

Fredman, S. (1998) Women and the Law. Oxford: Oxford University Press.

Fredman, S. (2004) Women at Work: The Broken Promise of Flexicurity. Industrial Law Journal, 33, 299-319.

Giddens, A. (1998) The Third Way: the Renewal of Social Democracy. Cambridge: Polity Press.

Gorz, A. (1999) Reclaiming Work: Beyond the Wage Based Society. Cambridge: Polity Press. 
Hepple, B. (2001)Equality and Empowerment for Decent Work. International Labour Review, 140, 5-18.

Janoski, T. (1998). Citizenship and Civil Society Society: A Framework for Rights and Obligations in Liberal, Traditional and Social Democratic Regimes. Cambridge: Cambridge University Press.

Kelly, G.H. (2000) Employment and Concepts of Work in the New Global Economy. International Labour Review. 139, 5-32.

Kessler, L. (2001) The Attachment Gap: Employment Discrimination Law, Women's Cultural Care giving, and the Limits of Economic and Liberal Legal Theory. University of Michigan Journal of Law Reform, 34, 371-468.

Klein, N. (2000). No Logo. Great Britain: Flamingo.

Kohler, T. (1995) Civic Virtue at Work: Unions as Seedbeds of the Civic Virtues. Boston College Law Review, 36, 279-304.

McAllister, J. (1998). Sisyphus at Work in the Warehouse: Temporary Employment in Greenville, South Carolina. In Barker, K and Christensen K. (eds) (1998) Contingent Work: American Employment Relations in Transition. New York: Cornell University Press.

Murphy, J.B. (1993) The Moral Economy Of Labor: Aristotelian Themes In Economic Theory. New Haven and London: Yale University Press.
New Zealand Council of Trade Unions (2004) A Union Guide To Work-Life Balance. Wellington: New Zealand Council of Trade Unions.

Pateman, C. (1970) Participation and Democratic Theory. Cambridge: Cambridge University Press.

Schultz, V. (2000) Life's Work. Columbia Law Review, 100, 1881-1964.

Sennet, R. (1998) The Corrosion of Character: the Personal Consequences of Work in the New Capitalism. New York: W.W. Norton and Company.

Supiot, A. (2001) Beyond Employment: Changes in Work and the Future of Labour Law in Europe. Oxford: Oxford University Press

Stone, K.V.W. (2001) The New Psychological Contract: Implications of the Changing Workplace for Labor and Employment Law. UCLA Law Review, 48, 519.

Toynbee, P. (2004) Hard Work: Life in Low Pay Britain Great Britain: Bloomsbury Publishing.

Tucker, D (2002) Precarious Non Standard Employment - A Review of the Literature. New Zealand: Labour Market Policy Group, Department of Labour. 